\title{
FORECAST MODEL TO OPTIMIZE THE PREPARATION ON BALANCE BEAM
}

\author{
Bonka Dimitrova, Neli Tankusheva, Marina Petrova
}

\begin{abstract}
Summary
The selection in a multi-year aspect is an indelible part of the scientifically grounded organization and management of the preparation of the sports reserve (Nikitushkin, 2009; Rosin, 2007; Dimitrova, 2014). It is based on the comprehensive study and characterization of athletes' athletic abilities and creating of possible most realistic forecasting models (Sivash, 2012; Chernuhina, 2004). The purpose of our research is to create a competitive model of the balance beam for our best gymnast in girls. To achieve the goal, we have produced model features of elite athletes in Europe for the surveyed age in 2015-2017, based on their participation and presentation at major competitions during this period. On the basis of the discovered parameters with the testing method and the analyzed stage of our gymnast training, we have prepared an individual optimized predictive model for the balance beam. The research showed that the actual achievement of the desired level of technical preparedness requires a change in the planned load in the different countries of the sports training. The comparative analysis identified the weak points in our contestant's subtitle. This allowed the development of new realistically achievable parameters of the forecasting model and a new corrected preparation plan.
\end{abstract}

Key words: technique, difficulty, model characteristic

\section{Introduction}

The selection in a multi-year aspect is an indelible part of the scientifically grounded organization and management of the preparation of the sports reserve (Nikitushkin, 2009; Rosin, 2007; Dimitrova, 2014). It is based on comprehensive study and characterization of athletes' athletic abilities and the forming of possible most realistic forecasting models (Sivash, 2012; Chernuhina, 2004).

The comparative analysis of the difficulty of the routines of the Bulgarian national competitors and the world elite from OG'2012 in London (Dimitrova, 2015) showed that the exercises they have mastered and routines of different apparatuses, constructed according to their capabilities, are far from those of the best. This has led us to construct a competitive capable predictive model for an age group of women, of our gymnast who participated in the European Championship (EC) for juniors in 2016. The selection of this contestant had to be carried out according to the following criteria:

> Level of technical and physical preparation;

$>$ Participation and ranking of international competitions;

> Psychological stability;

$>$ Motivation and desire for victory.
The study showed that we do not have a complex competitor who meets our requirements. This led us to only one apparatus - the beam, where our representative would have been the best chance of success. In the process of multiannual preparation in artistic gymnastics increases the reliability and stability of performance of various gymnastic exercises, connection from them and competition routines (Smolevski, Gaverdovsky, 1999). The beam is a kind of gymnastic all around that symbolizes the accuracy and grace of the motion action on a small support area. Many authors point to this apparatus as a "checkpoint" for successful performance in various competitions (Dimitrova, 2002; Dondi, 2007).

\section{Aim and Objectives of the study}

The purpose of our research is to create a competitive model of the balance beam routine of for our best gymnast in junior, given its upcoming participation in women's competitions for 2018. In order to achieve this goal we have set the following tasks:

- To create model characteristics for the technical training of elite gymnasts in Europe for the test age in 2015-2017, based on their participation and presentation at major competitions during this period.

- To testing and analyze the physical and technical preparation of our gymnasts.

- To create an individual optimized forecast model for the apparatus beam 


\section{Methods}

In our work, we used the methods of observation, testing, modeling and analysis. The subject of our study is the routines of the beam and the object are the exercises determining the technical difficulty. We have analyzed 36 beam routines of competitors from the world elite and in our country.

\section{Results}

We have analyzed the beam routines of the best competitors on this apparatus in 2015 and 2016, respectively - the European Youth Olympic Festival, 2015 (EYOF'2015) and the European championship for juniors - 2016 (EC'2016).

Table 1 Results of the C I - Qualifications on beam for juniors of the EYOF'2015

\begin{tabular}{|c|c|c|c|c|c|c|c|c|}
\hline \multirow{2}{*}{$\begin{array}{l}\text { Ranking } \\
\text { (place) }\end{array}$} & \multirow[t]{2}{*}{ Name } & \multirow[t]{2}{*}{ Nationality } & \multicolumn{2}{|c|}{ D-score (points) } & \multicolumn{2}{|c|}{ E-score (points) } & \multicolumn{2}{|c|}{ Final score (points) } \\
\hline & & & & Difference & & Difference & & Difference \\
\hline 1. & D. Skrypnik & RUS & 5,80 & & 8,500 & & 14,300 & \\
\hline 2. & A. Klinkaret & BEL & 6,00 & $+0,20$ & 8,300 & $-0,200$ & 14,300 & 0,000 \\
\hline 3. & N. Derwael & BEL & 5,60 & $-0,20$ & 8,400 & $-0,100$ & 14,000 & $-0,300$ \\
\hline 4. & I.T.Crisan & ROU & 5,90 & $+0,10$ & 8,100 & $-0,400$ & 14,000 & $-0,300$ \\
\hline 5. & Z. Kovacs & HUN & 5,70 & $-0,20$ & 8,050 & $-0,450$ & 13,750 & $-0,550$ \\
\hline 6. & M.R. Metheuen & GBR & 5,30 & $-0,50$ & 8,400 & $-0,100$ & 13,700 & $-0,600$ \\
\hline 7. & M. Maggio & ITA & 5,60 & $-0,20$ & 8,050 & $-0,450$ & 13,650 & $-0,650$ \\
\hline 8. & A. Iliankova & RUS & 5,40 & $-0,40$ & 8,100 & $-0,400$ & 13,500 & $-0,800$ \\
\hline Average EYOF'2015 & & & 5,663 & & 8,238 & & 13,900 & \\
\hline
\end{tabular}

Table 2 Results of the C I - Qualifications on beam for juniors of the EC'2016

\begin{tabular}{|c|c|c|c|c|c|c|c|c|}
\hline \multirow{2}{*}{$\begin{array}{l}\text { Ranking } \\
\text { (place) }\end{array}$} & \multirow[t]{2}{*}{ Name } & \multirow[t]{2}{*}{ Nationality } & \multicolumn{2}{|c|}{ D-score (points) } & \multicolumn{2}{|c|}{ E-score (points) } & \multicolumn{2}{|c|}{ Final score (points) } \\
\hline & & & & Difference & & Difference & & Difference \\
\hline 1. & A. Iliankova & RUS & 5,80 & & 8,483 & & 14,283 & \\
\hline 2. & E. Eremina & RUS & 5,40 & $-0,40$ & 8,866 & $+0,383$ & 14,266 & $-0,017$ \\
\hline 3. & L. Charpy & FRA & 5,70 & $-0,10$ & 8,475 & $-0,008$ & 14,175 & $-0,055$ \\
\hline 4. & I.T.Crisan & ROU & 6,00 & $+0,20$ & 8,133 & $-0,350$ & 14,133 & $-0,150$ \\
\hline 5. & P. Borzykh & GEO & 6,00 & $+0,20$ & 8,033 & $-0,450$ & 14,033 & $-0,250$ \\
\hline 6. & A. Kinsella & GBR & 5,60 & $-0,20$ & 8,400 & $-0,083$ & 14,000 & $-0,283$ \\
\hline 7. & M.R. Metheuen & GBR & 5,80 & 0,00 & 8,133 & $-0,350$ & 13,933 & $-0,350$ \\
\hline 8. & H. Schaefer & GER & 5,70 & $-0,10$ & 8,100 & $-0,383$ & 13,800 & $-0,483$ \\
\hline Average EC'2016 & & & 5,75 & & 8,328 & & 14,078 & \\
\hline 52. & R. Ranchova & BUL & 5,20 & $-0,60$ & 6,966 & $-1,517$ & 12,166 & $-2,117$ \\
\hline
\end{tabular}

Table 1 and 2 show the results of the first eight of age for the elite, which leads to a final score -12.116 Competition I - Qualifications (C I). The model features of elite gymnasts from the C I, show that the difficulty score is within the range of $5.30-6.00$ points and the average of the model is 5,663 . The results are no different than these of the EC'2016. There, the average difficulty in routines is 5.75 points. This reveals the continuous growth in the level of technical readiness for excellence in gymnastics.

The difficulty score (D-score) of our competitor - 5.2 p. - comes close to the best, which shows us the potential of success. In the execution score (E-score), however, it is nearly two points lower than the averp. In Figure 1 shows the level of the Bulgarian participant in the EC'16 and the values of the model characteristics of the best for the studied competitions. The study showed that the actual achievement of the desired level of technical preparedness is possible given the difficulty, which has reached for the moment. Improving performance, in our opinion, is related to the level of the competitor's physical qualities. Therefore, to prepare the forecasting model we studied the level of physical and technical preparation during the transition to the age group - women. For this purpose, we analyzed the attestations for the national team in 2016-2017. 


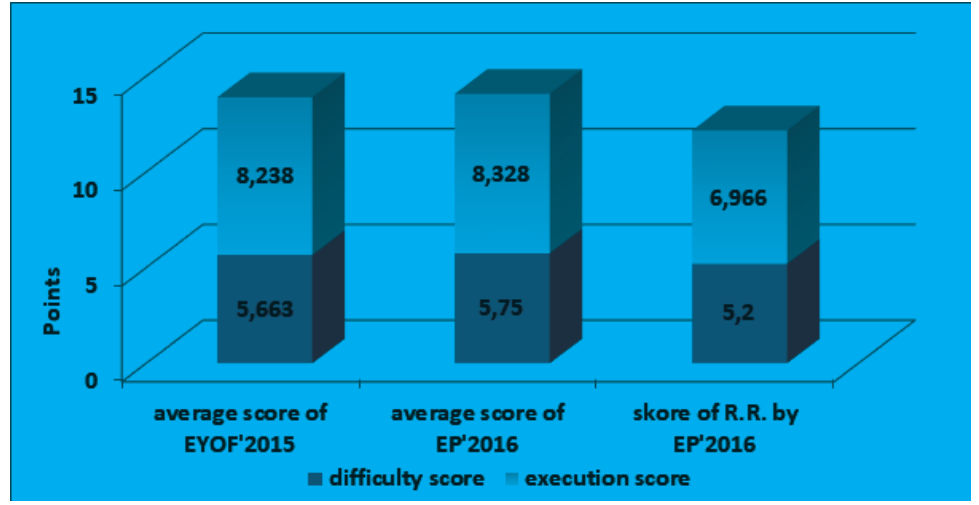

Figure 1 Average final score of the beam from Competition I - Qualifications of the eight finalists from EMOF'2015 and EC'2016 and the R.R. - BUL, participant of the EP'16

The analysis of the results of the national team attestation (Table 3) of our competitor identified the weak units in its preparation. The technical readiness of the beam (Table 4) has the largest contribution to the overall excellent score on this side of the sport preparation.

Table 3 Results in points, from conducted national team attestation junior - 06-07.02.2017

\begin{tabular}{|c|c|c|c|c|c|c|c|c|c|c|}
\hline Name & $\begin{array}{c}\text { Competition } \\
\text { II -AA }\end{array}$ & 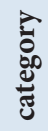 & $\begin{array}{c}\text { Technical } \\
\text { preparation }\end{array}$ & $\begin{array}{l}\text { ह0 } \\
\text { है } \\
\text { है }\end{array}$ & $\begin{array}{c}\text { Physical } \\
\text { preparation }\end{array}$ & 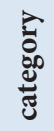 & $\begin{array}{l}\text { Trampoline } \\
\text { preparation }\end{array}$ & 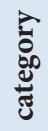 & Total & $\begin{array}{l}\text { Dे } \\
\text { क्ष } \\
\text { है }\end{array}$ \\
\hline R. R. & 48.300 & III & 91 & I & 95 & IV & 3 & II & 237.300 & III \\
\hline
\end{tabular}

Table 4 Results in points, from conducted national team attestation junior - Competition II - AA 06-07.02.2017

\begin{tabular}{|c|c|c|c|c|c|c|c|c|c|c|c|c|c|}
\hline \multirow[b]{2}{*}{ Name } & \multicolumn{3}{|c|}{$\boldsymbol{T}$} & \multicolumn{3}{|c|}{ 吕 } & \multicolumn{3}{|c|}{$\Pi$} & \multicolumn{3}{|c|}{$\square$} & \multirow[b]{2}{*}{$\begin{array}{l}\text { Total } \\
\text { scoring }\end{array}$} \\
\hline & D-score & E-score & $\begin{array}{l}\text { Final } \\
\text { score }\end{array}$ & D-score & E-score & $\begin{array}{l}\text { Final } \\
\text { score }\end{array}$ & D-score & E-score & $\begin{array}{l}\text { Final } \\
\text { score }\end{array}$ & D-score & E-score & $\begin{array}{l}\text { Final } \\
\text { score }\end{array}$ & \\
\hline R. R. & 4.00 & 8.60 & 12.600 & 1.90 & 8.00 & 9.900 & 5.50 & 7.80 & 13.300 & 4.60 & 7.90 & 12.500 & 48.300 \\
\hline
\end{tabular}

Table 5 Results of R. R. from the attestation of technical preparation for a national team of girls 07.02.2017

\begin{tabular}{|c|c|c|c|c|c|c|c|c|c|c|c|c|c|c|c|c|c|}
\hline Apparatus & & 1 & & & 吊 & & & & & & & & & & & & \\
\hline \multirow{2}{*}{$\begin{array}{l}\text { Difficulty of the } \\
\text { executed exercise }\end{array}$} & \multirow{2}{*}{ D } & \multirow{2}{*}{ E } & \multirow{2}{*}{ Total } & \multirow{2}{*}{ D } & \multirow{2}{*}{ E } & \multirow{2}{*}{ Total } & \multicolumn{2}{|c|}{ D } & \multicolumn{2}{|c|}{ E } & \multirow{2}{*}{ Total } & \multicolumn{2}{|c|}{ D } & \multicolumn{2}{|c|}{ E } & \multirow{2}{*}{ Total } & scoring \\
\hline & & & & & & & G & A & G & A & & G & A & G & A & & \\
\hline $\begin{array}{l}\text { Number of exer- } \\
\text { cises }\end{array}$ & - & - & - & 2 & - & 2 & 5 & 6 & 1 & - & 12 & 3 & 3 & 1 & 1 & 8 & 22 \\
\hline \multirow{2}{*}{ Number of points } & \multirow{2}{*}{ - } & \multirow{2}{*}{ - } & \multirow{2}{*}{0} & \multirow{2}{*}{8} & \multirow{2}{*}{0} & \multirow{2}{*}{8} & 20 & 24 & 5 & - & \multirow{2}{*}{49} & 12 & 12 & 5 & 5 & \multirow{2}{*}{34} & \multirow{2}{*}{91} \\
\hline & & & & & & & \multicolumn{2}{|c|}{44} & \multicolumn{2}{|c|}{5} & & \multicolumn{2}{|c|}{24} & \multicolumn{2}{|c|}{10} & & \\
\hline
\end{tabular}

Note: They are respected technically correctly executed exercises with difficulty D and more. Each vault with a value of 4.50 to 5.00 point by the Code of points - FIG is group D - 0.4 p.; E - 0.5 p. and etc. On the beam and floor ex. exercises can be gymnastic $(G)$ and acrobatic (A). 
Table 5* Evaluation table for level of technical preparation for national team - juniors.

\begin{tabular}{|l|c|c|c|c|c|}
\hline Evaluation on technical preparation & excellent & very good & good & medium & poor \\
\hline Number of points & more than 90 & $76-89$ & $66-75$ & $51-65$ & under 50 \\
\hline
\end{tabular}

Table 6 Results of an attestation on physical preparation for national team juniors - 07.02.2017

\begin{tabular}{|c|c|c|c|c|c|c|c|c|c|c|c|c|c|c|c|c|c|}
\hline \multirow{3}{*}{ 芩 } & \multicolumn{16}{|c|}{ Physical preparation tests for national team junior } & \multirow{3}{*}{ 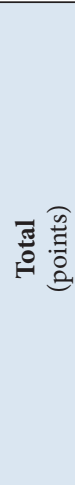 } \\
\hline & \multicolumn{2}{|c|}{ 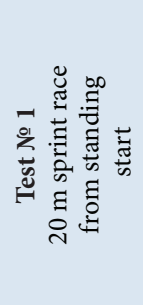 } & \multicolumn{2}{|c|}{ 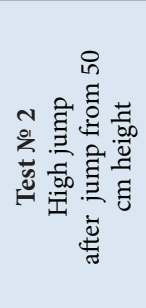 } & \multicolumn{2}{|c|}{ 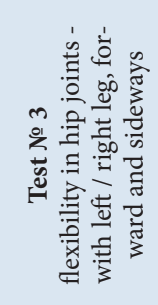 } & \multicolumn{2}{|c|}{ 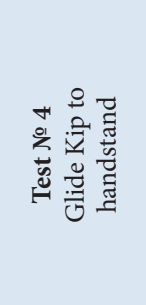 } & \multicolumn{2}{|c|}{ 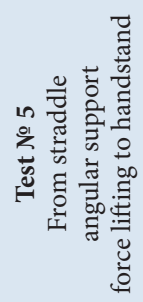 } & \multicolumn{2}{|c|}{ 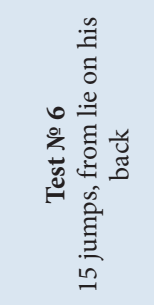 } & \multicolumn{2}{|c|}{ 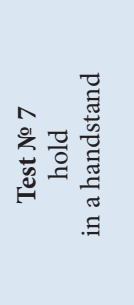 } & \multicolumn{2}{|c|}{ 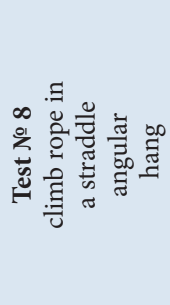 } & \\
\hline & $\ddot{凶}$ & . & हี & $\begin{array}{l}\stackrel{0}{\Xi} \\
\stackrel{\Xi}{0}\end{array}$ & 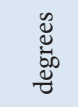 & $\begin{array}{l}\stackrel{0}{\leftrightarrows} \\
\stackrel{0}{0}\end{array}$ & 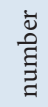 & . & 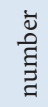 & $\begin{array}{l}\stackrel{0}{\leftrightarrows} \\
\stackrel{0}{0}\end{array}$ & $\ddot{\varpi}$ & .气 & $\ddot{\mathscr{\infty}}$ & : & $\ddot{\mathscr{\varpi}}$ & 苛 & \\
\hline R.R. & 3,31 & $\mathbf{0}$ & 48 & 15 & 163,5 & 34 & 11 & 35 & 2 & 5 & 31,58 & 6 & 10 & $\mathbf{0}$ & 0 & $\mathbf{0}$ & 95 \\
\hline
\end{tabular}

Note: The maximum value for each test is 50 points, i.e. for 8 tests - the maximum is 400 points

Table 6* Evaluation table for level of physical preparation for national team - juniors.

\begin{tabular}{|l|c|c|c|c|c|}
\hline Evaluation on physical preparation & excellent & very good & good & medium & poor \\
\hline Number of points & $321-400$ & $241-320$ & $161-240$ & $81-160$ & $1-80$ \\
\hline
\end{tabular}

The advantage absorption of acrobatic and gymnastic exercises on beam and floor exercises, with great difficulty ( $\mathrm{D}$ and $\mathrm{E}$ ) and the lack of such or extremely insufficient of the other two apparatuses - vault and uneven bars, reveal gaps or unilateralities in preparation (Table $5,5^{\star}$ ). This is due, according to us, to the level of physical training of the gymnast. Its physical fitness does not correspond to the high aspirations for realization. From a possible 400 points, it has only 95 (Table $6,6^{*}$ ), which according to the rating scale gives her average grade at the physical preparation. The table shows that with a maximum of 50 test points, R.R. has a relatively good set of points 34-35 in just two tests for flexibility and for force. That is why we consider one of the requirements for the gymnast's entry in the world elite is the better physical preparation, especially work for speed, force, explosive force and endurance.

The analysis of performance of routines in a competitive environment of our gymnast shows that she makes more mistakes on more responsible competitions. This reveals a lack of psychological stability in a more complex setting. We suppose that the ex- istence of competition, poor physical training lead to greater uncertainty and implementation mistakes. Unlike these competitions, the presentation of state championships and national attestations of the apparatus beam in most cases is an indicator of stability, confidence and high technical level. This gives us reason to build a predictable model competing with the world's elite.

\section{Discussion}

According to the obtained results of the conducted study, we compiled a forecast model presented in Fig. The proposed beam's routine, consists of $17 \mathrm{ex}-$ ercises (Figure 2).

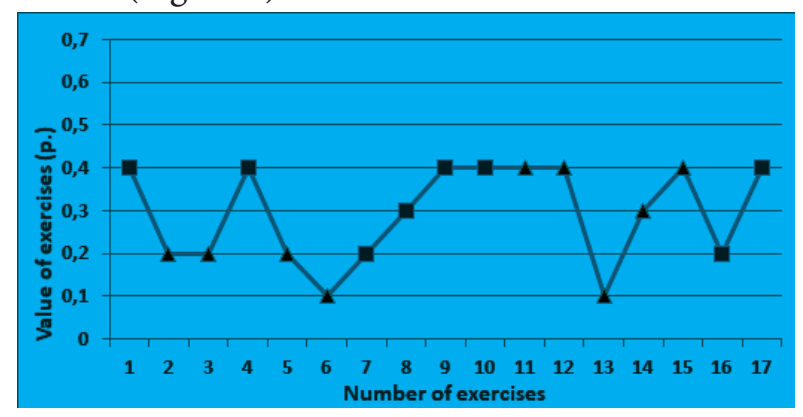

Figure 2 Composite Structure of the Projected Model of the routine of a beam for R. R. - BUL for 2018 


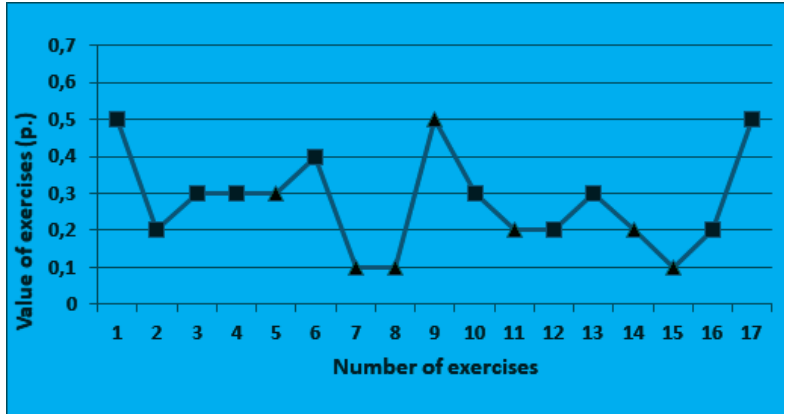

Figure 3 Compositional structure of the beam routine of K. Ponor - ROU from the EC'2017 for women

According to the FIG rules, for difficulty are considered only 8 exercises ( 3 gymnastic and 3 acrobatic and 2 optional), usually those that have the highest value. The estimated difficulty is 3.2 points. In this way, the combination fulfills the composition requirement, which adds another 2.0 points and is represented possible connections from exercises of value -0.8 points. Thus, the estimated $\mathrm{D}$-score is 6.0 points. The model characteristic of the best gymnast of the beam for the period under consideration (Figure 3 ) gives us the parameters of the sought-after sporting perfection. The comparison of the two models shows that our competitor has a higher initial score of 0.1 point. The individual gifting of our gymnast to this model is an essential prerequisite for the success. Finally, we can draw the following conclusions:

- The individual forecasting model thus constructed by us is an objective consequence of the mastered volume of acrobatic and gymnastic exercises from R.R.
- The proposed compositional structure of the beam routine and suggested connections from exercises is actually achievable and competitive for the 2018 competitive year.

\section{References}

Dimitrova, B. (2002), Gimnasticheska greda - metodika, ravnovesie, sporten rezultat, B-INS, Sofia, in Bulgarian Dimitrova, B. (2014), Teoriya na podbora, sportna gimnastika - zheni, B-INS, Sofia, in Bulgaria

Dimitrova, B. (2015), Sistema za podgotovka I optimizirane na obuchenieto $\mathrm{v}$ sportnata gimnastika, B-INS, Sofia, in Bulgaria

Dondi, A. (2007), Nadezhnost vipolneniya gimnasticheskih prizhkov na brevne, Disertacia, St. Petersburg

Nikitushkin, V, G. (2009), Sovremennaya podgotovka yunih sportsmenov, Moscow

Rozin, E. Y. (2007), Metodicheskie aspekti otbora I problem sportivnogo otbora, Fizitsheskaiya kultura, Moscow Sivash, I. S. (2012), Sportivnij otbor I orientaciya v sisteme mnogoletnego sovershenstvovaniya gimnastok v grupovih uprazhneniyah hudozhestvennoi gimnastiki, V.F.S., № 1

Smolevski, V., Gaverdovski, Y. (1999), Sportivnaiya gimnastika, Olimpiiskaiya literatura, Kiev, 462

Chernuhina, O. V. (2004), Otbor sohraneniya detei v sporte, Fizitsheskaiya kultura, 1, Moscow

\section{Prof. Bonka Dimitrova, PhD}

Assoc. Prof. Neli Tankusheva, PhD

Head Assist. Marina Petrova, PhD

National Sports Academy

Department of Gymnastics

Studentski grad, 1700 Sofia, Bulgaria

E-mail: boni07@abv.bg 